American Journal of Environmental Sciences 6 (1): 83-89, 2010

ISSN 1553-345X

(C) 2010 Science Publications

\title{
Sustainable Development through Waste Heat Recovery
}

\author{
${ }^{1}$ P.S. Bundela and ${ }^{2}$ Vivek Chawla \\ ${ }^{1}$ Madhya Pradesh Pollution Control Board, Vijay Nagar Jabalpur Madhya Pradesh, India \\ ${ }^{2}$ Associated Cement Corporation Kymore, Katni Madhya Pradesh, India
}

\begin{abstract}
Problem statement: Waste Heat Recovery (WHR) steam Technology is a proven Technology pioneered by Japanese for cement plant and it is economically viable. Electrical Power can be generated by adopting the latest technology in this field. It used a medium to low temperature (120$350^{\circ} \mathrm{C}$ ) Turbine technology (standard thermal power plants run on steam temp-500 ${ }^{\circ} \mathrm{C}$ ). Approach: It requires treat exchangers $(\mathrm{Hx})$ designed for high dust load, no additional fuel is required Kymore Cement Works has proposed to install a power plant of $9 \mathrm{MW}$ which will be operated with the recovered waste heat from the clinker coolers and kilns from its both clinker units. The hot air from cooler and kiln passes through the ESP is taken to the waste heat recovery exchangers. Adequate size of heat-exchangers will be located at proper locations in order to achieve optimum temperature of Thermic Oil from waste gases. Conclusion/Recommendations: This is required for optimal power yield. The hot flue gases will pass through a Heat Exchanger by which the temperature (heat of the waste gas is transferred to the internal elements of the heat exchangers which is used for heating of the thermo oil. In turn this thermal oil vaporizes the organic fluid in close loop cycle. Multi level pressure turbine system will be installed which increases usable heat content resulting in higher power output. The turbine will be run by the organic vapors to generate the electrical energy. The system of oil collection, oil transfer to the vaporizer and its recycling process will be made for the complete recycling of the thermal oil.
\end{abstract}

Key words: Cement, waste heat, recovery, thermal power, clinker

\section{INTRODUCTION}

India, being the second largest cement producer in the world after China with a total capacity of 151.2 Million Tones (MT), has got a huge cement industry. With the government of India giving boost to various infrastructure projects, housing facilities and road networks, the cement industry in India is currently growing at an enviable pace. More growth in the Indian cement industry is expected in the coming years. It is also predicted that the cement production in India would rise to 236.16 MT in FY11. It's also expected to rise to 262.61 MT in FY12 (Al-Hinti, 2006).

Environmental impacts of waste heat: The environmental impacts which may result from the discharge of waste heat to the environment may be separated into two general categories: (1) those impacts resulting from the release to the environment of the various chemical and particulate pollutants contained in the waste heat stream and (2) those impacts resulting from the release to the environment of the heat energy contained in the waste heat stream (Barker et al., 2009).
The environmental impacts resulting from the release of pollutants are specific to the composition and volume of each discharge. However, any action which results in an increase in the efficiency of energy utilization (whether it is accomplished by waste heat recovery or general conservation practices) may be considered as a pollution control alternative in that these actions will result in a reduction in fuel consumption and, generally, in a corresponding decrease in the quantity of pollutants discharged. The greatest potential impact of waste heat discharges is to natural bodies of water and their aquatic ecosystem. Although a large number of studies have been and are being conducted in attempts to further define these cause and effect relationships, considerable data are still lacking. Some of the known and reported effects associated with temperature increases of natural waterways are: decreasing gas (oxygen) solubilities; changes in species diversity, metabolic rates, reproductive cycles, digestive and respiration rates and behavior of the aquatic organism; and increasing the parasitic bacterial population. All of these have the potential for creating an unbalanced aquatic ecosystem (Chakrabarti, 2002).

Corresponding Author: P.S. Bundela, Madhya Pradesh Pollution Control Board, Vijay Nagar Jabalpur Madhya Pradesh, India 
Emerging technologies: The coal conversion processes currently under development range in overall energy conversion efficiencies from a low of $38 \%$ for the Fisher-Tropsch coal liquefaction process to a high of $80 \%$ for the low Btu gas synthesis process. This overall efficiency is defined as the heating value of the refined fuel products divided by the heating value of the coal feedstock. The result indicates that a large percentage of the heating value of the feedstock is rejected into the environment. If energy self-sufficiency is to be realized, it could be assumed that imported fuels would be replaced by domestic fuels converted from coal (Engin and Ari, 2005).

Carbon dioxide emissions from the cement production process: Carbon dioxide emissions in cement manufacturing come directly from combustion of fossil fuels and from calcining the limestone in the raw mix. An indirect and significantly smaller source of $\mathrm{CO}_{2}$ is from consumption of electricity assuming that the electricity is generated from fossil fuels. Roughly half of the emitted $\mathrm{CO}_{2}$ originates from the fuel and half originates from the conversion of the raw material (Gautam et al., 2009a).

Carbon dioxide emission from calcination (process emissions): Process $\mathrm{CO}_{2}$ is formed by calcining which can be expressed by the following equation (Gautam et al., 2009a):

$\mathrm{CaCO}_{3}>\mathrm{CaO}+\mathrm{CO}_{2}$

$1 \mathrm{~kg} 0.56 \mathrm{~kg}+0.44 \mathrm{~kg}$

The share of $\mathrm{CaO}$ in clinker amounts to $64-67 \%$. The remaining part consists of iron oxides and aluminum oxides. $\mathrm{CO}_{2}$ emissions from clinker production amounts therefore at about $0.5 \mathrm{~kg} \mathrm{~kg}^{-1}$ clinker. The specific process $\mathrm{CO}_{2}$ emission for cement production depends on the ratio clinker/cement. This ratio varies normally from 0.5-0.95 (Ashenayi and Ramakumar, 1990).

Carbon dioxide emissions from fuel use: Practically all fuel is used during the production of the clinker. The preprocess removes water from the raw meal, calcines the limestone at temperatures between 900 and $1000^{\circ} \mathrm{C}$ and finally clinker the kiln material at about $1500^{\circ} \mathrm{C}$. The amount of carbon dioxide emitted during this process is influenced by the type of fuel used (coal, fuel oil, natural gas, petroleum coke, alternative fuels) (Gautam et al., 2009b).

The total $\mathrm{CO}_{2}$ emission during the cement production process depends mainly on:
- Type of production process (efficiency of the process and sub-processes)

- Fuel used (coal, fuel oil, natural gas, petroleum coke, alternative fuels)

- Clinker/cement ratio (percentage of additives)

The carbon dioxide emission from the cement production (dry and wet-process) in relation to the clinker/cement ratio and fuel used. The cement/clinker ratio may vary by adding more or less additives to the cement. Not accounted for are the carbon dioxide emissions attributable to mobile equipment used for winning of raw material, used for transport of raw material and cement and used on the plant site (Rasul et al., 2006).

Global carbon dioxide emission from cement production process: World average primary energy intensity was $4.8 \mathrm{MJ} \mathrm{kg}^{-1}$ cement, with the most energy intensive regions being Eastern Europe and the former Soviet Union (5.5 MJ kg-1), North America (5.4 $\mathrm{MJ} \mathrm{kg}^{-1}$ ) and the Middle East (5.1 $\mathrm{MJ} \mathrm{kg}^{-1}$ ). Estimated carbon dioxide emissions from cement production in 1994 were $1126 \mathrm{Tg} \mathrm{CO}, 587 \mathrm{Tg} \mathrm{CO}$ from process emissions and $539 \mathrm{Tg} \mathrm{CO}$ from energy use. These emissions account for $5 \%$ of 1994 world carbon emissions based on a total of $22.7103 \mathrm{Tg} \mathrm{CO}_{2}$ (6.2 GtC) reported by the Carbon Dioxide Information and Analysis Center. The average world carbon intensity of carbon emissions in cement production is $0.81 \mathrm{~kg} \mathrm{CO}_{2} \mathrm{~kg}^{-1}$ cement. While China is the largest emitter, the most carbon intensive cement region in terms of carbon emissions per $\mathrm{kg}$ of cement produced is India $\left(0.93 \mathrm{~kg} \mathrm{CO} \mathrm{kg}^{-1}\right)$, followed by North America $\left(0.89 \mathrm{~kg} \mathrm{CO}_{2} \mathrm{~kg}^{-1}\right)$ and China $\left(0.88 \mathrm{~kg} \mathrm{CO}_{2}\right.$ $\left.\mathrm{kg}^{-1}\right)$.

Reduction of carbon dioxide emissions: Emissions of carbon dioxide can be reduced by: (1) Improvement of the energy efficiency of the process. (2) Shifting to a more energy efficient process (e.g., from (semi) wet to (semi) dry process. (3) Replacing high carbon fuels by low carbon fuels. (4) Applying lower clinker/cement ratio (increasing the ratio additives/cement): Blended cements. (5) Application of alternative cements (mineral polymers). (6) Removal of $\mathrm{CO}_{2}$ from the flue gases.

Replacing high-carbon fuels by low-carbon fuels: More than $90 \%$ of the energy used in the cement production is originating from fuels. The rest (5-10\%) of the primary energy consumption is electricity. A main option to reduce carbon dioxide emissions is to 
reduce the carbon content of the fuel: e.g., shifting from coal to natural gas. An important opportunity to reduce the (long-cycle) carbon emission is the application of waste-derived alternative fuels. This could at the same time diminish the disposal of waste material and reduces the use of fossil fuels. Disadvantage may be the adverse effects on the cement quality and increased emission of harmful gases. Some types of alternative fuels: Gaseous alternative fuels (Coke oven gases, refinery gases, pyrolisis gas, landfill gas); Liquid alternative fuels (Halogen-free spend solvents, mineral oils, distillation residues, hydraulic oils, insulating oils); and Solid alternative fuels (Waste wood, dried sewage sludge, plastic, agricultural residues, tyres, petroleum coke, tar) (Rasul et al., 2006).

The European cements industry used in 1990 between 0.75 and $1 \mathrm{Tg}$ per year of secondary fuels, equivalent to 25-35 PJ. In 1993, 9\% of the thermal energy consumption in the European cement industry originated from alternative fuels. A number of issues should be considered while using waste-derived fuels: (i) Energy efficiency of waste combustion in cement kilns; (ii) constant cement product and fuel quality; (iii) emissions to atmosphere; (iv) trace elements and heavy metal; (v) alternative fate of waste; and (vi) production of secondary waste. Waste processing in the cement industries is feasible and current practice. Waste as alternative fuel is increasingly used in cement plants. Waste may reduce $\mathrm{CO}_{2}$ emissions by $0.1-0.5 \mathrm{~kg} \mathrm{~kg}^{-1}$ cement produced compared to current used production techniques using fossil fuels. The use of waste generates no additional emissions, although care should be taken for high volatile elements as mercury and thallium. On the other hand, the use of waste does not impair clear environmental advantages, besides the reduction of substituted fossil fuels (Sincero and Sincero, 1996).

Carbon dioxide removal: Reduction of carbon dioxide emissions can be obtained by applying carbon dioxide removal. In this technique, $\mathrm{CO}_{2}$ is separated during or after the production process and subsequently stored or disposed of outside the atmosphere (Barker et al., 2009). In some cases the recovered $\mathrm{CO}_{2}$ can be used for other purposes. The $\mathrm{CO}_{2}$ removal process can be split into three separate steps: Recovery of the $\mathrm{CO}_{2}$ (often including drying and compressing), transport of the $\mathrm{CO}_{2}$ to a location where it is handled further and utilization, storage or disposal of $\mathrm{CO}_{2}$. The $\mathrm{CO}_{2}$ can be recovered from the flue gases, originating from the calcination process as well as from the combustion processes. Typical $\mathrm{CO}_{2}$--concentrations in the flue gases range from 14-33\%. Because of the high share of
$\mathrm{CO}_{2}$ in flue gases originating from the calcination process (and not from a combustion process), combustion in a $\mathrm{CO}_{2} / \mathrm{O}_{2}$ atmosphere may, a priori, be a promising technique to recover the $\mathrm{CO}_{2}$. A chemical absorption process seems to be less appropriate because of the high heat requirement of the process. In the $\mathrm{CO}_{2} / \mathrm{O}_{2}$ technique oxygen instead of air is used for the combustion, i.e., the nitrogen diluent is removed in an air separation plant before the fuel is Oxidized. A problem in this approach is the high stoichiometric combustion temperatures. This problem can be solved and even turned into an greenhouse gas control technologies conference paper-cement, advantage, by recycling produced $\mathrm{CO}_{2}$. In this way adding more or less recycled $\mathrm{CO}_{2}$ can control the combustion temperature. The $\mathrm{CO}_{2}$ in these systems acts as the required temperature moderator. An additional benefit is that all impurities are stored underground and that the need for DeSOx or DeNOx facilities is not present. Experiences with this technique have been gained in Japan and the United States. In these experiments the main focus lay on the electricity production facilities. In the scope of this study a preliminary calculation on the energy requirement has been made: assuming 90\% capture efficiency, dry process (3.35 $\mathrm{MJ} \mathrm{kg}^{-1}$ clinker), clinker/cement ratio of 0.95 and fuel oil as fuel, the total required power consumption will be about $0.86 \mathrm{MJe}$. The total $\mathrm{CO}_{2}$ production amounts then to $1.08 \mathrm{~kg} \mathrm{~kg}^{-1}$ cement and the overall capture efficiency amounts to $70 \%$. The net $\mathrm{CO}_{2}$ emissions amounts then to 0.32 $\mathrm{kg} \mathrm{kg}^{-1}$ cement (Table 1). At this stage of research, however, it is not clear whether this technique can be applied to cement production facilities. Various questions remain unsolved like the influence on the combustion medium on the calcination process, whether or not the process can be sufficiently leak-free. Cost estimates are therefore not available yet (Davis and Cornwell, 1998).

Process description and brief of the technology: A Waste Heat Recovery (WHR) system (Rasul et al., 2005) converts waste thermal energy from a pre-heater (Temp. 300-400 Deg C) and /or Clinker cooler (Temp. 270-350 Deg C) into electrical energy. (1) Heat sourceKiln pre-heaters and clinker coolers. (2) It requires heat-exchangers (HX) designed for high dust load. (3) No additional fossil fuel is required. (4) Thermal Oil Circuit or waster circuit system for vaporizer. (5) With the exhaust from a 4800 TPD kiln line, approx, 4 MW electrical power can be generated. 
Am. J. Environ. Sci., 6 (1): 83-89, 2010

Table 1: Comparison of steam Rankine and organic Rankine cycle

\begin{tabular}{ll}
\hline Steam Rankine cycle & Organic Rankine cycle \\
\hline $\begin{array}{l}\text { Larger ducts and pipes thereby } \\
\text { having much higher waste heat } \\
\text { losses }\end{array}$ & $\begin{array}{l}\text { Smaller ducts and pipes thereby } \\
\text { having very low waste heat } \\
\text { losses }\end{array}$ \\
$\begin{array}{l}\text { Requires DM water and } \\
\text { chemicals feed }\end{array}$ & $\begin{array}{l}\text { No DM water/chemicals feed } \\
\text { needed }\end{array}$ \\
$\begin{array}{l}\text { Generates wastewater requiring } \\
\text { additional treatment }\end{array}$ & $\begin{array}{l}\text { Does not generate any solid, } \\
\text { liquid or gas waste streams }\end{array}$ \\
$\begin{array}{l}\text { Expected Life 15-20 years as } \\
\text { steam condensation possible }\end{array}$ & $\begin{array}{l}\text { Proven turbine life } 30+\text { years as } \\
\text { no condensation }\end{array}$ \\
$\begin{array}{l}\text { Approx. cost of installation-Rs. } \\
\text { 8-9 Cr MW } \text { MW }^{-1}\end{array}$ & $\begin{array}{l}\text { Approx. cost of installation-Rs. } \\
\text { 9-10 Cr MW }\end{array}$ \\
\hline
\end{tabular}

The technology for waste heat utilization of kiln coolers are either based on water use for generation of steam or based on organic chemical (Pentane) for Turbo Generator. The waste heat recovery systems are of two types: (1) Steam Rankine cycle (2) Organic Rankine cycle. Kymore Cement Works has proposed to install the technology for power generation on the principle of "Organic Rankine Cycle" The process of the proposed $9 \mathrm{MW}$ power plant will be based on the above principle and technology in which the fuel will be the waste heat generated and being wasted from the cement plant clinker coolers (2 nos.) of Kymore Cement Works of about $4800 \mathrm{MT}^{\mathrm{May}}{ }^{-1}$ clinker capacity each. The above technology is used for arresting the waste heat as fuel and utilizing the heat energy for heating thermal oil which in turn will evaporate the organic chemical (Pentane). The Pentane vapors shall be used to operate the Turbo Generator thereby producing power. The cooler flue gas is passed through the ESP for dust collection will be routed through the Heat Exchanger by which the temperature (heat) of the waste gas is transferred to the internal elements of the heat exchangers which is used for heating the thermal oil. The system of oil collection, oil transfer to the vaporizer and its recycling process is made for the complete recycling of the thermal oil. The Cooler hot air passes through the ESP of clinker Cooler is taken to the waste heat recovery exchangers (Utlu et al., 2006).

Basic Design parameters of the Heat Recovery system (Total for clinker coolers and pre-heaters of both clinker units at Kymore Cement Works. (1) Gas Design Mass Flow rate: 1120 Tons $^{-1}$. (2) Oil heater inlet gas Temperature: $320^{\circ} \mathrm{C}$ (Design). (3) Oil heater outlet gas Temperature: $150^{\circ} \mathrm{C}$. (4) Max. Dust loading: $50 \mathrm{mg} \mathrm{Nm}^{-3}$ (for Cooler)-60 gm NM${ }^{-3}$ (for Kiln). (5) Ave. dust particle size: 15 Microns. (6) Air pressure after ESP: $30 \mathrm{~mm}$ WC (7) Ambient Temp.: 35 Deg C (Design-Average) (Worell et al., 2000).

\section{Power output parameters:}

- Waste heat recovered: $55 \mathrm{MW}$ (thermal)

- Gross out put: $9 \mathrm{MW}$ (electrical)
- Net out put: $7 \mathrm{MW}$.

Mass balance:

- Thermic fluid flow rate: $512 \mathrm{TPH}$

- Temperature at inlet: $120^{\circ} \mathrm{C}$

- Temperature at out let: $270^{\circ} \mathrm{C}$

- Quantity: 200 tons

- Expected reduction in $\mathrm{CO}_{2}$ emission 48000 tons year $^{-1}$

Salient features of proposed Waste Heat Recovery (WHR) system for power generation:

- WHR system is specially designed for high dust laden gases

- Provided with special mechanized soot removal and collection system

- Waste heat recovery system is provided with a bypass arrangement so that it will not affect the original process

- System is designed to take care of sticky gases from Pre heater as well as Abrasive gases from clinker cooler exit

- Power output matched automatically the fluctuations of cooler exhaust Temperatures

- No additional staff for operating the system and no interference with the kiln operations

- Operation and maintenance costs negligible

- Savings in power

- Design facilities thermal expansion of all tubes eliminating possibility of thermal stresses.

Air pollution control: For pre-heater gases: The dusty pre-heater gases after coming out of WHR System shall be cleaned in the existing dedusting facility consisting of Electrostatic Precipitator (ESP). Which is proposed to be replaces by Bag House for lower emission and better reliability.

For clinker coolers gages: The dusty cooler gases shall be cleaned with the help of existing dedusting facility consisting of Electrostatic Precipitator (ESP). Thus cleaned gases pass through the waste heat recovery system.

Water use: No water will be required for the proposed project.

No impact to thermal oil/pentane on environment: There will be no impact of thermal oil and Pentane on the environment, since both are used in the closed 
circuit. Moreover, the oil and pentane are kept in recirculation after each cycle of heat generation and hence there is no waste generation and disposal of these two.

Noise: Ambient air noise level shall be maintained below the norms.

Benefits of waste heat recovery: Classified under two categories:

- Direct:

- Has a direct effect on the efficiency of the process, reduction in fuel costs and CDM benefits

- Elimination of cooling water (e.g., GCT in Cement kiln or Sponge Iron kiln)

- Indirect

- Reduction in pollution:

- Several toxic material like CO, plastic and oil sludge. when burnt in Incinerators does dual functions of providing potential for waste heat recovery as well as reducing the air pollution

- Reduction in equipment size:

- Reduction in fuel consumption will result in reduction in flue gas generation and hence the equipment handling the flue gases like pollution control device, fan and Stack. shall be compact

- Reduction in Auxiliary energy consumption:

- Reduced equipment size will result in lowering the auxiliary power consumption

Prerequisites of waste heat recovery system: Sources and usage of waste heat temperature of $>240^{\circ} \mathrm{C}$ (for industrial applications) and $>120^{\circ} \mathrm{C}$ (for geothermal applications): (1) Quantum of recoverable waste heat (this decides the economical viability). (2) Upset conditions that may occur due to usage of heat recovery system. (3) Space availability. (4) Any other constraints (Yan et al., 2009).

Technology options and comparison: (1) Steam Rankine cycle. (2) Organic Rankine cycle. (3) Kalina cycle.

\section{Kalina cycle:}

- It is a thermodynamic cycle for converting thermal energy to electrical energy with the help of two fluids (mainly water and ammonia 70:30)

- Ammonia and water vapor stream is pressurized and then expanded in the turbine to generate electrical energy
- The remaining ammonia-water stream rejoins with the high pressure water stream and condenses to form 70-30 liquid ready for reuse

- However associated with some risk of corrosion

Organic Rankine cycle: Salient features of the system:

- Waste heat recovery system is specially designed for high dust laden gases

- Provided with special mechanized soot removal and collection system

- High dust level readily accepted

- Waste heat recovery system is provided with a bypass arrangement so that it will not affect the original process

- System is designed to take care of sticky gases from pre heater as well as abrasive gases from clinker cooler exit

- OEC availability of over $98 \%$ achieved

- Actual measured output (corrected) was 2\% higher than those predicted by design

- Power output matched automatically the fluctuations of cooler exhaust temperatures

- No additional staff hired for operating the system

- No interference with operators main tasks

- Operation and maintenance costs negligible

- Provided phenomenal savings in power

- Saved 6000 tons per year per MW of $\mathrm{CO}_{2}$

- Design facilities thermal expansion of all tubes eliminating possibility of thermal stresses. In case of such systems, thermal stress is a main source for leakages of welding joints

- Unique design of expansion tank, maintains surface temperature below $100^{\circ} \mathrm{C}$ eliminating possibility of oxidation

- Due to bare tube construction, dependence on manufacturer is reduced in case of repairs. In case of finned tubes, similar tube availability after 1012 years could be a problem

- Very low difference in bulk and film temp of Thermic Fluid. This increases life of Thermic fluid considerably

\section{CONCLUSION}

A system for the utilization of dissipated heat from the surfaces of cement processing kilns in cement factories in heating heavy fuel oil used in the burning process of these kilns. It is proposed that this can be achieved by circulating thermal oil inside large coil- 
shaped tubing which is placed around the kiln's shell. The heated thermal oil then transfers the recovered heat to the heavy fuel oil inside a heat exchanger. This is intended to effectively reduce the cost of energy (both electricity and diesel fuel) currently used to heat the heavy fuel oil to facilitate its pumping to the processing kilns. The proposed system can also be considered as an environment-friendly system since it utilizes available wasted energy and reduces the resulting emissions of cement production processes.

The one of three flexible mechanisms of the Kyoto Protocol, has received noticeable attention in cement industry. Making fully use of the opportunity brought by clean development mechanism can help cement enterprises in India to recover the waste heat generated in the process of cement production. Implementing the development of clean development mechanism projects in cement industry field, mainly focusing on waste heat for power generation projects, can not only reduce environmental pollution, but also bring certain economic and social benefit. It is in favor of promoting the upgrade of cement industrial structure and will contribute to positive and farreaching effect toward sustainable development of cement industry in India.

The manpower for the proposed $9 \mathrm{MW}$ power plant in ACC Kymore (MP) India is proposed to be 12 no. which is for the complete project during operation after installation. Since water will not be required in the process, there will not be any man power involved for; any water management in the plant, in view of no manpower is required for water management. The Annual capacity of the proposed installation is $9 \mathrm{MW}$ Captive Power Plant by use of waste heat recovery from both clinker units of Kymore Cement Plant. This information has missed in the application. The information regarding cost of project is for the complete project, in which no water management is required. The proposed power generation plant on waste heat recovery system from the existing clinker units, based on Organic Rankine Cycle type having installation cost of about 9-10 cores per MW plant. So, the proposed cost is 90 crores for $9 \mathrm{MW}$ WHR plants, which does not include any cost for any water management as no water is required in the process.

For installing the Head recovery ACC Kymore Cement Industry would utilize the waste heat of cement plant clinker cooler and pre-heaters hot gases. This will be another environment friendly step in; the modernization of Kymore Cement Works. The plant for power generation by waste heat recovery will be another milestone for Kymore Cement Works contribution to the environment and sustainable development.

\section{ACKNOOLEDGEMENT}

The researchers are thankful to ACC Kymore Cement staffs for laboratory facilities and also thank to Madhya Pradesh Pollution Control Board, Bhopal for his support.

\section{REFERENCES}

Al-Hinti, I., 2006. Energy saving potentials in Jordan through the introduction of diesel passenger cars. WSEAS Trans. Environ. Dev., 2: 479-501.

Ashenayi, K. and R. Ramakumar, 1990. IRES-A program to design integrated renewable energy system. Energy, 12: 1143-1152.

Barker, D.J., S.A. Turner, P.A. Napier-Moore, M. Clark and J.E. Davison, 2009. Carbon Dioxide Capture in the Cement Industry. 3rd Edn., McGraw-Hill Inc., pp: 583-589.

Chakrabarti, B.K., 2002. Investigation on heat loss through the kiln shell in magnesite dead burning process: A case study. Applied Therm. Eng., 22: 1339-1345.

Davis, M.L. and D.A. Cornwell, 1998. Introduction to Environmental Engineering. 3rd Edn., McGrawHill Inc., pp: 683-689.

Engin, T. and V. Ari, 2005. Energy auditing and recovery for dry type cement rotatry kiln systemsA case study. Energy Convers. Manage., 46: 551-562.

Gautam, S.P., Bundela P.S. and V. Chawla, 2009a. Coprocessing of plastic waste with coal in the cement kiln. J. Solid Waste Technol. Manage., 24: 1173-1179.

Gautam, S.P., R.K. Jain, B.N. Mohapatra, S.M. Joshi and R.M. Gupta, 2009b. Energy recovery from solid waste in cement rotary kiln and its environmental impact. J. Solid Waste Technol. Manage., 24: 1187-1198.

Rasul, M.G., W. Widianto and B. Mohanty, 2005. Assessment of the thermal performance and energy conservation opportunities of cement industry in Indonesia. Applied Therm. Eng., 25: 2950-2965.

Rasul, M.G., I. Faisal and M.M. Kamal Khan, 2006. Environmental pollution generated from process industries in Bangladesh. J. Environ. Pollut., 28: 144-161.

Sincero, A.P. and G.A. Sincero, 1996. Environmental Engineering. Prentice-Hall Inc., pp: 386-387. 
Utlu, Z., Z. Sougut, A. Hepbasli and Z. Oktay, 2006. Energy and energy analyses of a raw mill in a cement production. Applied Therm. Eng., 26: 2479-2489.

Worell, E., N. Marti and L. Pryce, 2000. Potential for energy efficiency improvement in the US cement industry. Energy, 25: 1189-1214.
Yan, Q., C.B. Zhou, P. Qu and R. Zhang, 2009. The promotion of clean development mechanism to cement industry capturing waste heat for power generation in China. Mitigat. Adapt. Strat. Global Change, 14: 783-804. 